\title{
Matematika dalam Multimedia Flipbook: Kreatifitas Guru dalam Pengembangan Media Pembelajaran dalam Meningkatkan Minat Siswa
}

\author{
Wendha Adha Juliasnyah ${ }^{12}$, Nunuk Suryani13, Leo Agung S $^{14}$ \\ wendha.ajs@gmail.com
}

\begin{abstract}
This research aimed to find out: (1) how was the condition of instructional process in mathematics in five grade of SD Muhmmadiyah 1 Ngawi, (2) the suitable developmental procedure of Flipbook as a multimedia for mathematics in SD Muhammadiyah 1 Ngawi, (3) the effectiveness of Flipbook in increasing students' motivation. This research designed in Research and Development study design corridor with procedures; (1) analyzing the needs needed in developing the Product, (2) designing prototypical product, (3) developing the product, (4) implementing the product in the field, and (5) evaluating product's weaknesses. In addition, this study used totally 52 samples. 26 samples in experimental group (five graders in Billal Bin Robbah class) and 26 samples in control group (five graders in Khadijah Binti Kubro class). Furthermore, in collecting the data, the researcher used questionnaire and achievement test as the instruments and it was analyzed using Descriptive statistic methods and ttest. After Administering the data analyses, it was found that: (1) the category of the product was good based on the means of points given by Content Expert-4, 74; (2) the category of the product was good based on the means of points given by Media Experts-4, 66), (3) the product considered very good based on first field test with means of 4,67 or $78 \%$; (4) the product also considered very good based on second field test with means of 4, 57 or $91 \%$; (5) $H_{1}$ was accepted, means that achievement of the two groups was different shown by the means (Experimental Group-72,38 and Control Group-63.83). The result of the $t$-test was interpreted based on parameter; $t D K=\{t t<-1.706$ or $t>1.706\}$ and $t_{\text {obs }}=8.048$ Z DK. In other word $\mathrm{H}_{0}$
\end{abstract}

Keywords: Mathematics, Multimedia, Flipbook, ADDIE. Instructional Media, Motivation

\footnotetext{
12 Alumni Magister Teknologi Pendidikan Universitas Sebelas Maret 


\section{PENDAHULUAN}

B anyak siswa yang menganggap., bahwa matematika itu adalah mata pelajaran yang membosankan dan bahkan ada yang sampai membenci. Hal ini, disebabkan kesulitan siswa dalam memahami apa yang disampaikan oleh guru, walaupun pada waktu proses pembelajaran siswa sudah berusaha keras untuk memperhatikan, tentu saja hal itu sangat menyulitkan para guru untuk mengajar. Sekuat apa pun guru berusaha menjelaskan., tetap saja pada umumnya siswa belum mampu untuk mencapai kompetensi dari tujuan pembelajaran yang ditetapkan, karena sudah dari awal para siswa kurang meminati matematika karena sulitnya materi yang perlu dipahami.

Peran matematika sangat penting bagi para siswa., Hal ini sesuai pernyataan Suherman (2001: 58) bahwa "Matematika di sekolah berperan dalam melatih siswa berpikir logis, kritis dan praktis, serta bersikap positif dan berjiwa kreatif'. Menyikapi hal tersebut maka seorang guru yang profesional haruslah kreatif dalam proses pembelajaran dikelas, agar mata pelajaran matematika yang selama ini dibenci atau kurang diminat itu dapat menjadi mata pelajaran yang menyenangkan bagi siswa. Untuk mencapai tujuan tersebut, maka proses pembelajaran pada satuan pendidikan haruslah diselenggarakan secara interaktif, inspiratif, menyenangkan, menantang, memotivasi siswa untuk berpartisipasi aktif, serta memberikan ruang yang cukup bagi prakarsa, kreativitas, dan kemandirian sesuai dengan bakat, minat, dan perkembangan fisik serta psikologis siswa (Peraturan Pemerintah No.19, 2005:Bab IV pasal 19 ayat 1).

Dalam era perkembangan IImu Pengetahuan, Teknologi dan Seni (IPTEKS) yang sekarang sudah sangat maju, profesionalisme guru dalam menyampaikan informasi (transfer knowledge) kepada siswa tidaklah cukup hanya dengan cara berbicara atau berceramah di depan kelas, tetapi guru sebaiknya harus mampu mengemas bentuk informasi itu ke dalam bentuk yang lebih menarik agar minat belajar siswa dapat lebih ditingkatkan.

Pemanfaatan teknologi dalam pendidikan saat ini memiliki peran dan posisi penting dalam pelaksanaan kegiatan pembelajaran. Januszweski \& Molenda (2008) mendefinisikan teknologi pendidikan sebagai suatu kajian ilmu dan praktek etis yang memfasilitasi belajar, meningkatkan kinerja dengan menciptakan, menggunakan dan mengelola proses-proses serta sumber teknologi yang sesuai. Hal ini mengindikasikan tujuan utama teknologi pendidikan (membantu siswa dalam mencapai tujuan pembelajaran).

Sejalan dengan hal tersebut, maka pendidikan yang sekarang ini haruslah mengarah pada pemanfaatan teknologi., salah satu perwujudannya dengan memanfaatkan media pembelajaran berbasis teknologi atau pembelajaran berbantuan komputer (CAI). Dalam proses pembelajaran, pemilihan dan penggunaan media yang tepat diharapkan dapat berpengaruh terhadap pembelajaran yang dialami siswa dalam tujuan tercapainya kompetensi yang diharapkan dari siswa.

Salah satu media pembelajaran yang diharapkan dapat menciptakan suasana belajar yang menarik dan kondusif yaitu, dengan penggunaan bahan ajar teknologi audio visual atau salah satunya buku digital atau Buku Sekolah Elektronik (BSE)/e-book, tapi kali ini peneliti akan mengembangkan BSE tersebut dengan mengintegrasikan konten multimedia ke dalam BSE tersebut, dengan istilah multimedia Flipbook.

Multimedia Flipbook merupakan bentuk penyajian bahan belajar mandiri yang disusun secara sistematis ke dalam unit pem-belajaran terkecil, untuk mencapai tujuan pembelajaran tertentu yang disajikan ke dalam format digital yang didalamnya terdapat unsur multimedia, dan navigasi yang membuat 
pengguna lebih interaktif dengan media. Dengan adanya buku elektronik yang bersifat Flipbook, dimana dalam proses penyampaian informasinya melibatkan tampilan audio visual seperti teks, audio, video, grafis dan animasi, serta program tersebut pemakaiannya mudah dipahami dan diharapkan dapat dijadikan media pembelajaran yang baik. Sebagai tambahan, penggunaan multimedia Flipbook juga dapat meningkatkan minat belajar siswa dan juga dapat mem-pengaruhi prestasi atau hasil belajar siswa (Ramdania, 2013) dan meningkatkan pemahaman dan meningkatkan pencapaian hasil belajar (Nazeri, 2013).

Penelitian ini bertujuan untuk mengetahui: (1) pembelajaran Matematika di SD (2) Prosedur pengembangan produk multimedia Flipbook untuk mata pelajaran Matematika di SD (3) efektivitas penggunaan multimedia Flipbook dalam meningkatkan minat pada mata pelajaran Matematika di SD.

\section{METODE PENELITIAN}

Penelitian ini dilakukan di Sekolah dasar Muhammadiyah 1 Ngawi beralamat di Jalan Basuki Rahmat No.077 Kabupaten. Ngawi Provinsi Jawa Timur.

Penelitian ini merupakan penelitian pengembangan (Research and Development). Penelitian pengembangan digunakan untuk menghasilkan produk tertentu, dan menguji keefektifan produk tersebut (Sugiyono, 2013).

Desain pengembangan media yang digunakan adalah desain pengembangan Instruksional ADDIE (Analysis, Design, Development, Implementation, Evaluation) yang berorientasi pada produk (Molenda, 2008). Pada pelaksanaan dan penerapannya, Model ADDIE adalah: (1) Analysis yang dapat diartikan sebagai analisis kebutuhan awal pada anak SD untuk menentukan atau mendesain awal materi pembelajaran dimana nantinya sebagai kebutuhan Pembuatan Program Multimedia Pembelajaran, (2) Design dapat diartikan sebagai desain awal produk berdasarkan analisis kebutuhan dalam materi pengukuran waktu dan sudut pada anak kelas V, (3) Development yang dapat diartikan sebagai memproduksi program pembelajaran multimedia flipbook, (4) Implementation diartikan sebagai implementasi atau proses pengujian produk media pembelajaran multimedia flipbook, (5) Evaluation yang diartikan sebagai Evaluasi program Mutimedia Flipbook pembelajaran yang telah dihasil-kan dan di uji cobakan.

Subjek uji coba dalam penelitian adalah 26 orang siswa kelas. V Billal Bin Robbah (kelas eksperimen) dan 26 orang siswa kelas V Khadijah Binti Kubro (kelas kontrol)

Instrumen pengumpulan data yang digunakan yaitu angket dan lembar observasi pengamatan. Angket digunakan untuk mengevaluasi terkait media yang diberikan kepada ahli media untuk mengetahui penilaian ahli media terhadap media yang dikembangkan, dan angket terkait materi diberikan kepada ahli materi untuk mengetahui penilaian ahli materi terhadap materi yang sudah dikembangkan. Lembar observasi pengamatan digunakan untuk menelusuri minat belajar siswa.

Teknik analisis data yang digunakan yaitu analisis statistik deskriptif dan analisis uji t. Analisis statistik deskriptif digunakan untuk menganalisis dan mendeskripsikan data yang telah terkumpul berdasarkan lembar observasi pengamatan yang dilakukan oleh guru. Data kuantitatif dari hasil angket validasi kemudian diubah menjadi data kualitatif menggunakan skala lima, yaitu penskoran dari angka satu sampai dengan lima. 
Tabel 1. Konversi data kuantitatif ke dalam data kualitatif

\begin{tabular}{ccc}
\hline Interval Skor & Nilai & Kategori \\
\hline$X>4.21$ & 5 & Sangat baik \\
$3.40<X \leq 4.21$ & 4 & Baik \\
$2.60<X \leq 3.40$ & 3 & Cukup \\
$1.79<X \leq 2.60$ & 2 & Kurang \\
$X \leq 1.79$ & 1 & Sangat kurang \\
\hline
\end{tabular}

Uji-t digunakan untuk menghitung efektivitas produk yang bertujuan untuk mengetahui sejauh mana produk media pembelajaran berupa multimedia flipbook ini dapat meningkatkan minat belajar siswa. Data yang dianalisis dalam uji efektivitas ini yaitu nilai anak yang diperoleh dari Prettest kelompok eksperimen dan kelompok kontrol. Nilai rata-rata kedua kelompok tersebut kemudian dianalisis menggunakan uji-t.

\section{HASIL DAN PEMBAHASAN}

Pengembangan Multimedia Flipbook ini mengikuti prosedur pengembangan ADDIE dari Molenda. Tahap pertama yaitu analisis. Tahap analisis diawali dengan studi pustaka dan studi lapangan, setelah dilanjutkan dengan analisis kebutuhan. Tahap kedua yaitu desain. Empat langkah yang dilakukan pada tahap desain yaitu menetapkan Kompetensi Dasar, merumuskan tujuan pembelajaran, membuat storyboard, dan validasi desain oleh ahli. Tahap ketiga yaitu pengembangan. Pada tahap pengembangan diawali dengan validasi produk oleh ahli materi 2 orang dengan 10 aspek dengan jumlah keseluruhan 18 butir instrumen yang dimana rata-rata ahli materi pertama 4,82 dengan kategori sangat baik dan ahli materi kedua 4,65 dengan kategori sangat baik dan ahli media 2 orang dengan 2 aspek yaitu tampilan 10 item dan penyajian 7 item dengan jumlah keseluruhan 17 butir instrumen yang dimana rata-rata ahli materi pertama 4,71 dengan kategori sangat baik dan ahli materi kedua 4,61 dengan kategori sangat baik, setelah itu dilanjutkan dengan uji lapangan awal dengan jumlah sample 3 orang dengan tingkat tinggi, sedang dan rendah dilihat dari ujian Blok 1 memperoleh rata-rata 4,67 dengan kategori sangat baik dan uji lapangan utama jumlah sample 9 orang dengan tingkat tinggi 3 siswa, sedang 3 siswa dan rendah 3 siswa dilihat dari ujian Blok 1 memperoleh rata-rata 4,57 dengan kategori sangat baik. Tahap keempat yaitu implementasi. Tahap implementasi merupakan tahap uji coba kelompok besar dimana terdapat dua kelompok kelas (eksperimen dan kontrol). Kelompok eksperimen adalah kelompok siswa yang menggunakan Multimedia Flipbook, sedangkan kelompok kontrol adalah siswa yang menggunakan buku paket (tidak menggunakan Multimedia Flipbook). Tahap kelima yaitu evaluasi. Sebelum menjadi produk akhir, Multimedia Flipbook pada mata pelajaran matematika siswa kelas V semester gasal terlebih dahalu dilakukan uji kelayakan dan efektivitas produk. Hal ini dilakukan untuk mendapatkan produk yang layak dan berkualitas dari segi isi materi dan media itu sendiri. Setelah produk dinyatakan layak, maka media pembelajaran ini dapat digunakan dalam pembelajaran matematika, selanjutnya. Analisis kelayakan produk diperoleh dari data hasil pengisisan angket/lembar evaluasi dari ahli materi, ahli media, dan angket uji coba produk pada siswa, sedangkan efektivitas produk diperoleh dari hasil tes prestasi siswa.

Berikut adalah beberapa contoh tampilan media pembelajaran yang berupa multimedia flipbook. 


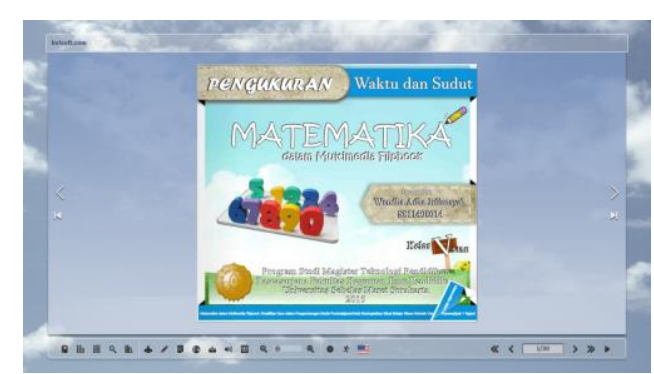

Gambar 1. Tampilan Cover

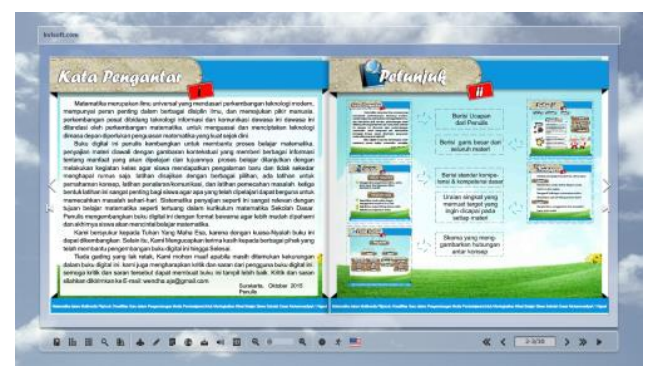

Gambar 2. Tampilan Kata Pengantar dan Petunjuk

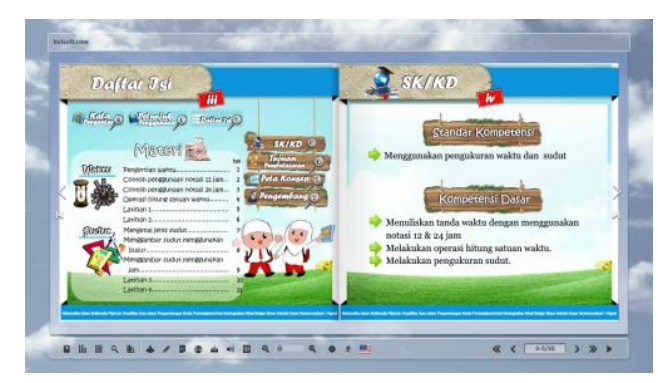

Gambar 3. Tampilan Daftar Isi dan SK/KD

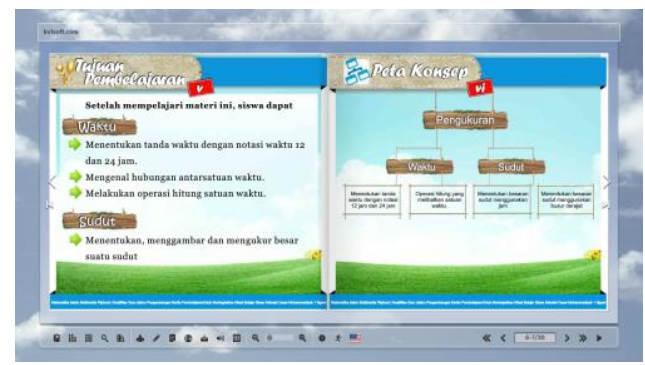

Gambar 4. Tampilan Tujuan Pembelajaran dan Peta Konsep

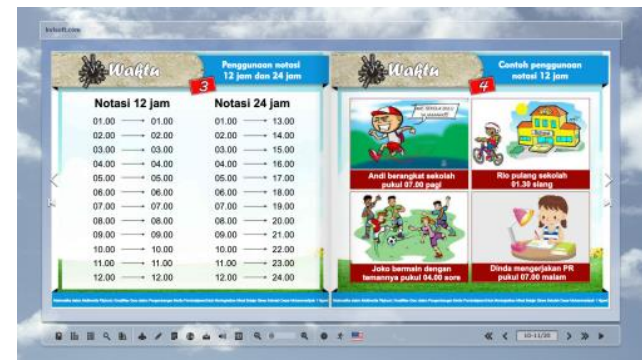

Gambar 5. Tampilan Materi Waktu 


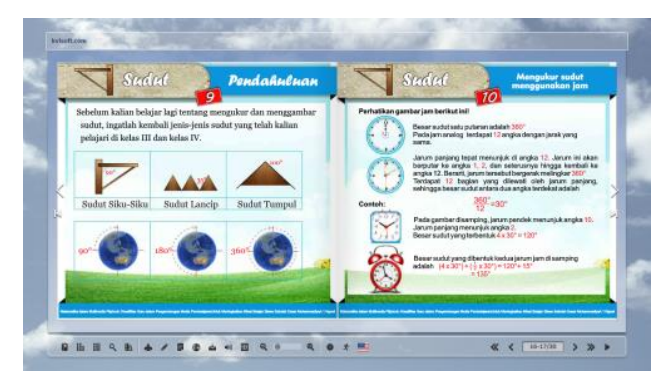

Gambar 6. Tampilan Materi Sudut

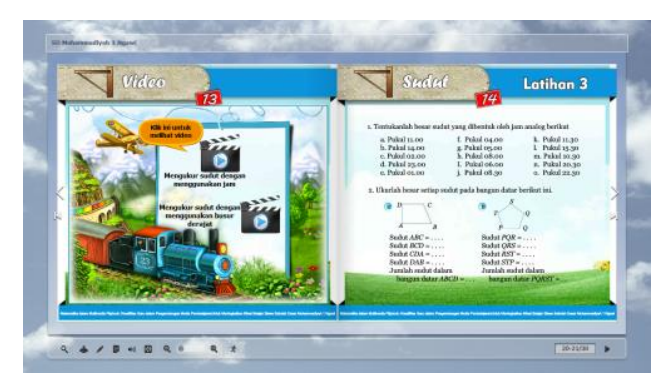

Gambar 7. Tampilan Video dan Latihan

Uji efektivitas produk dilakukan dengan menggunakan uji t. Sebelum dilakukan perhitungan uji t, terlebih dahulu dilakukan uji prasyarat (uji normalitas dan uji homogenitas). Hasil pengujian normalitas dan homogenitas menunjukkan bahwa kelompok eksperimen dan kelompok kontrol memiliki data yang berdistribusi normal dan homogen.

Setelah dilakukan uji prasyarat analisis, dilakukan analisis uji t. Hasil Uji Efektivitas menunjukkan bahwa minat belajar siswa yang menggunakan Multimedia Flipbook lebih baik dibandingkan dengan anak yang menggunakan buku teks. Hasil ini ditunjukkan dari perhitungan Uji t, dimana DK $=\{\mathrm{t} \mid \mathrm{t}<-1.706$ atau $t>1.706\}$ dan tobs $=8.048 \notin D K$. Keputusan uji adalah $H_{0}$ ditolak, sehingga dapat disimpulkan bahwa kedua kelompok memiliki prestasi yang tidak sama. Kelompok eksperimen memiliki rata-rata 72. Sedangkan kelompok kontrol memiliki rata-rata 63,38.

\section{PEMBAHASAN}

Berdasarkan hasil dari studi lapangan dan tahap analisis menunjukkan bahwa peran guru masih sangat mendominasi selama pembelajaran matematika berlangsung. Metode pembelajaran yang digunakan terbatas pada ceramah dan tanya jawab saja. Siswa tidak memiliki kesempatan untuk mengkonstruk pengetahuannya sendiri. Aktivitas siswa hanya mendengarkan dan mencatat materi yang disampaikan oleh guru. Media pembelajaran yang digunakan guru juga hanya buku paket matematika atau LKS. Hal ini lah yang pada akhirnya membuat sebagian besar siswa menjadi pasif dan cepat merasa bosan saat proses pembelajaran berlangsung. Untuk menciptakan suasana kegiatan belajar yang baru, inovatif dan dapat memotivasi anak untuk mudah memahami apa yang disampaikan khususnya untuk meningkatkan kemampuan membaca anak, perlu adanya penggunaan teknologi komputer yang ada, karena teknologi komputer ini sebenarnya dapat memberikan kontribusi yang sangat efektif untuk pembelajaran, seperti yang dikemukakan oleh Smaldino dkk.(2005) mengatakan bahwa media adalah suatu alat komunikasi dan sumber informasi. Maka dalam penggunaan media ini sangat amat efektif 
digunakan dalam pembelajaran agar dalam penyampaian pesan dan informasi tersebut dapat diterima dengan baik.

Karakteristik siswa yang aktif seharusnya dapat difasilitasi oleh guru dengan menciptakan suasana pembelajaran yang menarik dan menyenangkan. Matematika di sekolah berperan dalam melatih siswa berpikir logis, kritis dan praktis, serta bersikap positif dan berjiwa kreatif (Suherman, 2001). Menurut Dimyati (2006), Pembelajaran adalah kegiatan guru secara terprogram dalam desain instruksional, untuk membuat siswa belajar aktif, yang menekankan pada penyediaan sumber belajar. Salah satunya yaitu dengan menggunakan media pembelajaran yang menarik dan memiliki interaksi langsung dengan siswa. Media pembelajaran yang dapat diakses melalui perangkat komputer/laptop adalah alternatif media pembelajaran yang menarik bagi siswa karena dapat dioperasikan kapan dan dimana saja. Media yang berarti perantara, penyalur, sarana sehingga posisi media ini bukanlah pengganti guru sepenuhnya di kelas. Asyar (2012) media merupakan alat yang digunakan untuk menyalurkan pesan dan informasi dari pengirim pesan kepada penerima pesan. Sehingga ketika dikaitkan dengan proses pembelajaran pengertian media pembelajaran menjadi sarana, perantara yang digunakan guru untuk menyampaikan materi pelajaran guna mencapai tujuan pembelajaran yang diharapkan. Kata multimedia ini mengisyaratkan bahwa dalam penggunaannya melalui banyak (multi) sarana berarti juga melibatkan beberapa indera, yaitu indera penglihatan, pendengaran melalui teks, visual diam, gerak, dan audio dan media interaktif yang bisa memberikan kesan pembelajaran 2 arah. Multimedia pembelajaraan yang dikembangkan peneliti berusaha unntuk menampilkan asperk-aspek tersebut, yaitu dengan menampilkan animasi gambar, audio, baik yang melalui teks, visual gambar ataupun visual gerak.

Selaras dengan pendapat Haris dalam Wang (2008) yang menyebutkan bahwa penggunaan multimedia yang meliputi pengenalan dan penguatan aspek visual dalam presentasi dapat menciptakan lingkungan belajar yang aktif, meningkatkan perfoma siswa, membantu perkembangan tingkah laku yang positif melalui pembelajaran konsep yang kompleks, meningkatkan komunikasi serta dapat diadaptasi dalam semua model dan tingkat pembelajaran.

Oleh karena itu penggunaan media haruslah efektif dan memenuhi prinsip-prinsip yang ada terutama prinsip interaktivitas, karena prinsip interaktivitas ini dipandang sebagai salah satu aspek penting yang akan menetukan keterlibatan siswa dalam proses pembelajaran nantinya. Dalam hal ini penulis juga berpendapat hal yang sama dengan Vaughan (2008) yang menyebutkan bahwa multimedia yang digunakan harus menyatukan antara siswa dengan materi pelajaran yang diberikan yang bearti multimedia flipbook yang di kembangkan telah dapat mengatasi rasa kebosanan siswa. Jika siswa tertarik dengan apa yang mereka kerjakan, mereka akan menikmati proses pembelajaran dan memahami materi yang diberikan guru. Hal terpenting bahwa multimedia flipbook mampu meningkatkan minat belajar dan prestasi belajar siswa

Dengan dikembangkan media pembelajaran multimedia flipbook dalam pembelajaran matematika di kelas 5 SD dalam meningkatkan minat belajar siswa maka guru harus mengembangkan kreativitas dalam mengelola materi bahan ajar agar siswa dapat lebih mudah memahami materi baik itu didalam kelas maupun di luar kelas. melihat pentingnya pemanfaatan media pembelajaran sebagai upaya menciptakan pembelajaran yang menarik dan menyenangkan bagi siswa, maka peneliti tertarik mengembangkan Multimedia Flipbook pada mata pelajaran matematika siswa kelas V semester gasal.

Produk media pembelajaran multmedia flipbook pada mata pelajaran matematika kelas 5 semester gasal sebelum menjadi produk akhir terlebih dahulu dilakukan pengujian kelayakan produk. Hal ini 
dilakukan untuk mendapatkan hasil yang maksimal dan berkualitas dilihat dari segi isi materi maupun media itu sendiri. Setelah produk dinyatakan layak, maka produk ini dapat digunakan dalam pembelajaran matematika.

\section{KESIMPULAN}

Berdasarkan hasil penelitian dan pengembangan produk yang dilakukan, maka dapat ditarik kesimpulan sebagai berikut:

Hasil pengamatan terhadap pembelajaran matematika pada kelas V di SD Muhammadiyah 1 Ngawi dapat disimpulkan bahwa pembelajaran matematika masih menggunakan metode ceramah dan tidak menggunakan media pembelajaran penunjang dalam penyampaian materi, sehingga siswa menjadi bosan mengikuti pembelajaran, dan siswa membutuhkan media tambahan atau media penunjang untuk membantu siswa dalam mempelajari dan memahami materi pelajaran yang disajikan atau yang disampaikan guru di sekolah.

SD Muhammadiyah 1 Ngawi berpotensi untuk pengembangan multimedia pembelajaran ini karena sarana dan prasarana mendukung untuk pemnggunaan media pembelajaran berbasis teknologi informasi. SD Muhammadiyah 1 Ngawi sudah mengembangkan media pembelajaran namun jumlahnya masih terbatas sehingga perlu tambahan media salah satunya adalah multimedia pembelajaran ini.

Produk multimedia flipbook yang baik hendaknya memenuhi kriteria efektivitas, efisiensi dan daya tarik tersendiri supaya bisa dimanfaatkan secara optimal untuk peningkatan minat belajar. Selain itu produk multimedia flipbook ppembelajaran hendaknya sesuai dengan tingkat pertumbuhan dan kebutuhan anak sehingga sangat perlu dilakukan tahapan analisis pendahuluan. Multimedia pembelajaran multimedia flipbook bisa dipakai oleh siswa secara mandiri ataupun dalam bimbingan orang yang lebih tua yang mampu menguasai teknologi informasi dan komunikasi. Siswa diperbolehkan menggunakan secara mandiri selama siswa mampu mengoperasikan perangkat pembelajaran dengan baik dan aman.

\section{SARAN}

Beberapa hal yang peneliti sarankan sehubungan dengan pengembangan produk multimedia flipbook ini adalah:

1. Bagi siswa sebaiknya pada pemanfaatan multimedia flipbook ini bisa dibaca kapan saja dimana saja anak tetapi dalam pengawasan guru ataupun orang tua terutama dalam pengoperasian komputer.

2. Guru

a. Bagi guru sebelum menggunakan multimedia sebaiknya guru membaca petunjuk penggunaannya dan mencoba sendiri terlebih dahulu sebelum dipraktikkan dalam kelas

b. Guru sebaiknya mempersiapkan peralatan yang dibutuhkan sebelum melakukan pembelajaran

3. Sekolah.

a. Bagi sekolah hendaknya memberikan workshop dan pelatihan kepada guru sebagai upaya untuk memfasilitasi guru mata pelajaran untuk dapat membuat multimedia flipbook sehingga siswa dapat mempelajari materi pelajaran lebih dalam melalui perangkat komputer/ laptop kapan saja dan dimana saja. 
b. Bagi sekolah, multimedia ini bisa digandakan dalam jumlah besar untuk dipakai dikelas yang lain yang mempunyai materi yang sama

4. Bagi pengembang lain

a. Penelitian ini terbatas pada satu sekolah sehingga perlu penelitian lanjutan dengan menggunakan sampel yang lebih luas

b. Media yang dikembangkan belum mencakup keseluruhan kompetensi dasar yang harus dicapai siswa dalam satu semester, sehingga perlu pengembangan untuk pokok bahasan lain.

\section{DAFTAR PUSTAKA}

Anitah, S. (2009). Teknologi Pembelajaran. Surakarta : Yuma Pustaka.

Arsyad, A. (2013). Media Pembelajaran Edisi Revisi. Jakarta : PT Raja Grafindo Persada.

Cumaoglu, S. \& Torun, K. (2013). E-book versus Printed Matherials: Preferences of University Students. International journal of Contemporary Educational Technology, 4(2), hlm 121-135.

Budiyono. (2013). Statistika Untuk Penelitian Edisi ke-2. Surakarta : UNS Press.

Dimyati dan Mudjiono (2006). Belajar dan Pembelajaran. Jakarta: Rineka Cipta

Borg, Gall, \& Gall. (2007). Educational Research. New York : Pearson.

Ismail, Roesnita dan A.N, Zainab. (2005). The Pattern Of E-Book Use Amongst Undergraduates in Malaysia: A Case of To Know is To Use, 10(2), hlm 1-23.

Januszwenski, A. \& Molenda, M. (2008). Educational Technology. US: Taylor \& Francis Group.

Miarso, Y. (2005). Menyemai Benih Teknologi Pendidikan. Jakarta: Kencana

Putra, P. B. (2014). E-book dan Pasar Perbukuan Kini. Diunduh dari http://www.ristek.go.id

Rusman. (2012). Belajar dan pembelajaran Berbasis komputer (mengembangkan profesionalisme guru abad 21). Bandung: Alfabeta

Susilana, R. \& Riyana, C. (2008). Media Pembelajaran. Bandung: CV Wacana Prima

Suryani, N \& Agung, L. (2012). Strategi Belajar Mengajar. Yogyakarta: Ombak.

Smaldino et al. 2011. Instructional Technology \& Media for Learning Teknologi Pembelajaran dan Media untuk Belajar Edisi Kesembilan. Jakarta: Kencana.

Suherman, Erman dkk. (2001). Strategi Pembelajaran Matematika Kontemporer. Bandung: FMIPA UPI

Tim Penyusun. (2013). Buku Sumber Simulasi Digital. Jakarta: SEAMOLEC. 